\title{
Congenital enterovirus infection
}

INSERM

\section{Source}

INSERM. (1999). Orphanet: an online rare disease and orphan drug data base. Congenital enterovirus infection. ORPHA:292

Cong enital viral infections with enteroviruses (EV) including coxsackie viruses and ECHO viruses is an infectious embryofetopathy that have been reported to cause spontaneous abortion, stillbirth, fetal malformations and acute systemic illness in the newborn. 